\title{
DIFFERENTIAL DIAGNOSIS OF SUBJECTIVE WORKLOAD AND STYLES OF COPING WITH STRESS AMONG AIRCRAFT CREWMEMBERS
}

\author{
Jan F. TERELAK ${ }^{1,2}$, Aleksandra SZEWCZYK ${ }^{2}$ \\ ${ }^{1}$ Military Institute of Aviation Medicine, Department of Flight Safety, Warsaw \\ ${ }^{2}$ Cardinal Stefan Wyszyński University, Institute of Psychology, Warsaw
}

Source of support: Own sources

Author's address: J.F. Terelak, Military Institute of Aviation Medicine. Department of Flight Safety, Krasińskiego 54/56 Street, 01-755 Warsaw, Poland, e-mail: jterelak@wiml.waw.pl

Introduction: This publication concerns psychological characterization of workload and coping with stress among commercial aircraft crews.

Methods: Analysis was conducted on two study groups: experimental group - pilots $(n=19)$ and commercial aircraft cabin crew $(n=22)$, and control group - shopping mall employees $(n=28)$. Occupational task load was assessed using Polish version of NASA-TLX tool. Styles of coping with stress were evaluated using Polish version of Coping Inventory for Stressful Situations (CISS) by N.S. Endler and D.A. Parker.

Results: We validated differences between pilots and aircraft cabin crew and control group both with regard to the style of coping with stress as well as specifics of occupational burden.

Discussion: It was noted that assessment of both subjective workload and styles of coping with stress among pilots and aircraft personnel in comparison to control group also characterizes work specifics for both of those vocational groups.

Conclusions: Methods of studying subjective workload and styles of coping with stress may be used for differential diagnosis of task-related aspects of various vocations.

Keywords: pilots, aircraft personnel, workload, coping with stress

Tables: 3 • References: 28 • Full-text PDF: http://www.pjamp.com • Copyright $@ 2013$ Polish Aviation Medicine Society, ul. Krasińskiego 54/56, 01-755 Warsaw, license WIML・Indexation: Index Copernicus, Polish Ministry of Science and Higher Education 


\section{INTRODUCTION}

The goal of this work is the differential diagnosis of subjective workload and styles of coping with stress among aircraft personnel and merchants. Aircraft crewmembers are carefully selected to fulfill many requirements including psychological features, language skills, and physical fitness as well as, in case of stewardesses, physical appearance. Specific nature of this work forces crews to adapt to various, often stressful circumstances [25].

Any work performed by an individual is a source of stress for that individual. This burden may have a variety of substrates and therefore, different characters. Taking into consideration physiological criteria we may distinguish physical and psychological burden [15]. In this work the concept of stress burden will be narrowed to the idea of task load, which according to NASA definition is defined as a relationship between stress ensuing from attention resources required for completing the task in addition to physical burden and performance [9]. Factors that shape performance, including both internal (intelligence, knowledge, emotion, personality) and external moderators (fatigue, stress), influence human performance in various ways. Relationship between workload and performance is often represented by an inverted U-curve, where low performance is caused by a low (often related to sleep disorders) and high workload [11]. Challenges associated with measuring workload from empirical perspective contributed to development of a variety of concepts to a degree, which should influence one's performance [2]. In aviation technological progress as well as training of pilots and aircraft personnel are supposed to generate working conditions that ensure the highest level of security at the existing task burden $[21,28]$. In psychology burden may be analyzed from cognitive perspective (e.g. influence of the task on cognitive functions), through differentiation (individual differences determining burden level) or from a psychophysiological viewpoint (psychophysical cost related performance of the task) [17]. Studies regarding task burden are aimed at determining the level of involvement in operational actions and the following categories of assessment are used: performance, psychophysiological and subjective. The first category refers to the assumption that greater difficulty of the task is followed by increased requirements and therefore, individual's involvement in completion of the task. The second category concentrates on psychophysiological evaluation. The last one refers to the association between increased energy put into completion of the task and individual perception of effort. According to the definition accepted by the team from NASA research center task burden above all involves the individual, not the task itself [14]. Subjective experience of the person completing a given task is a sum of many factors and their impact in addition to objective requirements imposed by the task. These requirements encompass several aspects: task criteria, its structure (duration, performance procedures), operator's qualifications, environment of the task and operator's condition at the time of its performance. Evaluation of workload is associated with subjective assessment based on perception of the task itself and earlier experiences involving the same types of tasks [14].

Stress as an integral component of work of the aircraft personnel is present in aviation psychology as a variable modifying task burden. Human Error model by James Reason may be used for analysis of an airplane catastrophe resulting from a sequence of preceding events (antecents) [22]. Another variable related to workload is the ability to cope with it known in the literature as style of coping with stress [5].

According to literature data there is a complex interrelationship between stress and task load. Namely, stress is associated with excessive task load. However, it cannot be concluded with certainty that high task load is necessary for feeling stressed or that people experiencing high levels of task load are not satisfied with their work [18]. High stress level generated by excessive, from the perspective of one's abilities, work requirements may reduce individual's performance [7].

R. Parasumaran and P.A. Hancock propose a differentiation based on three aspects: stress, task load and fatigue [20]. From this perspective, requirements related to completion of a given task represent initial burden, strategies of coping with burden are called adaptation, while operator's response corresponds to performance. This system encompasses: insensitivity to task burden (together with a change in performance an individual adapts, no changes are noted in perception of task load), insensitivity to performance (individual experiences changes in perceived ask load with simultaneous attempt to maintain constant level of performance). Managing task burden based on the above-mentioned relationships enables better understanding of its structure. Coping with task load is influenced not only by the magnitude of initial load (requirements for completion of the 
task), but also by the rate of changes related to adaptation and preventative processes. B.H. Kantowitz and P.A. Casper further develop this concept, emphasizing multidimensional significance of task load, defining it as subjective experience produced by the association of motivation, capabilities, expectations, training, time, stress, fatigue and circumstances with the number, type and level of difficulty of the dictated task, effort and success of fulfilled requirements [14]. Standards considering mental workload may be applied to any other kind of work. Perceived costs may change depending on properly perceived performance and perceived consequences of a situation when all means of coping fail. An individual putting great effort to fulfill the requirements imposed by the task, who views his capabilities as inadequate, may feel concerned, frustrated or stressed. On that basis, stress and other negative emotion were considered by researchers as components of task load [18].

\section{METHODS}

At the background of differential diagnosis of task load and style of coping with stress as a component of task load among commercial aircraft crewmembers we may formulate the following hypothesis:

Hypothesis 1. There is a difference between subjective assessment of task load among commercial aircraft crewmembers and control group.

Work of aircraft crewmembers involves onboard operations encompassing complicated mental processes, perceptivity, attention, and ability to adapt to new circumstances, as well as physical work (carrying items, such as catering carts by aircraft cabin crew). Control group included ground personnel working in sales. As opposed to aircraft work this occupation requires, above all things, significant physical effort.

Hypothesis 2. There is a difference between aircraft crew and control group with regard to styles of coping with stress.

Aircraft crew exhibits a tendency for taskoriented style of coping with stress. Aircraft staff work requires quick reactions to problems and stressful situations taking place onboard as well as the ability to conceal emotion before patients.

Hypothesis 3. There is a difference between aircraft personnel and pilots in subjective task load assessment scale.

Aircraft cabin crew and pilots have different task structures and type of liability for passengers, which generate somewhat different tasks.

\section{Study group characteristics:}

Experimental group included pilots and commercial aircraft cabin crew. On the other hand, control group encompassed stationary shopping mall employees. Study included 19 pilots and 22 aircraft crewmembers. Ages of pilots ranged between 27 and 63 years, while aircraft cabin crewmembers were aged 21-31 years. The control group included 28 stationary employees of the airport, aged 20-57 years. Aircraft crew and subjects from the control group had secondary education or higher.

\section{Methodology:}

Workload was assessed using NASA-TLX tool. It is a subjective, multidimensional tool created by the Human Performance group at the main NASAAmes Research Center, used to evaluate stress level produced as a result of performing a given task or work [12]. Polish version of NASA-TLX was transcribed by M. Bicka-Capala (after Zielinski, Biernacki [1]) without interfering with the content and is an exact translation of the original English Version [2]. NASA-TLX task load index is based on six scales: (1) mental burden (Mental) (requirements of the task with regard to mental activity and perception as well as accuracy of execution), (2) physical burden (Physic) (magnitude of physical effort needed to perform a given task or involvement in work), (3) time pressure (Tempor) (time designated to a given task and the speed at which it is performed), (4) performance (Perfor) (achieved goals and satisfaction gained from achieving them), (5) Effort (Effort) - physical and mental energy used to execute the task at the highest performance level, (6) Frustration (Frustration) (feeling of dispiritedness, uncertainty, weariness, satisfaction, contentment).

Due to its structure NASA-TLX tool combines two evaluation methods. The first method consists of bipolar scales and the second of pairwise comparisons. If it is treated as a tool for evaluating individual differences reliability of NASA-TLX is satisfactory and does not fall below 0.75 . Theoretical accuracy was confirmed, i.a. in the analysis of intergroup differences $(p<0.05)$ and analysis of changes in non-accidental test results (Biernacki, Zielinski, 2010).

Styles of coping with stress were examined using Coping Inventory for Stressful Situations (CISS) by N.S. Endler and D.A. Parker [4]. Polish version of the questionnaire was developed by P. Szczepaniak, J. Strelau and Kazimierz Wrzesniewski [24]. Theoretical basis refer to transactional model of stress developed by R. Lazarus and S. Folkman 
[16]. CISS consists of 48 statements concerning various behaviors that people may present under stress. Results are presented in three scales: taskoriented style (TO), emotion-oriented style (EO) and avoidance-oriented style (AO). The latter may take on two forms: involvement in substitute activities (SA) or seeking social contact (SC). The tool possesses good psychometric properties.

\section{RESULTS}

Acquired results were subjected to statistical analysis conducted using IBM SPSS 21 software. Table 1 presents results of a Shapiro-Wilk test for normal distribution of variables in compared groups.

As shown by Table 1 close to normal distribution was acquired for all scales of SISS questionnaire in SA subscale. Distribution for SC subscale in a control group as well as distributions for all NASA-TLX questionnaire subscales in both groups was far from normal distribution (general distribution of results was close to normal in control group only). Therefore, non-parametric tests were used to verify research hypotheses for SC subscale and general result as well as for NASA-TLX subscales.

Differences between study group and control group with regard to the preferred styles of coping with stress were assessed using Student's t-test for all scales as well as SA subscale, and U Mann-Whitney test for SC subscale, which was characterized by nonnormal distribution of its control group. Before the ttest we used Levine's test to check for homogeneity of variance. In TO and AO scales variance proved to be heterogeneous. Results of tests for significance of differences are presented in Table 2.

We confirmed the hypothesis of greater tendency for task-oriented style of coping with stress among aircraft crew compared to control group (t $(44.97)=2.272 ; p<0.05)$. Study group used this style significantly more often $(M=65.12 ; S D=6.71)$ than control group $(M=60.39 ; S D=9.52)$. In order to evaluate the magnitude of acquired effect we calculated Cohen's d coefficient. Its value implies

Tab. 1. Results of a Shapiro-Wilk test for normal distribution of variables in compared groups.

\begin{tabular}{|c|c|c|c|c|c|c|}
\hline \multirow{2}{*}{ Scale } & \multicolumn{3}{|c|}{ Study group } & \multicolumn{3}{|c|}{ Control group } \\
\hline & w & df & $\mathbf{p}$ & $\mathbf{w}$ & df & $\mathbf{p}$ \\
\hline Tо & 0.963 & 41 & 0.193 & 0.936 & 28 & 0.086 \\
\hline EO & 0.987 & 41 & 0.903 & 0.946 & 28 & 0.156 \\
\hline AO & 0.955 & 41 & 0.102 & 0.938 & 28 & 0.099 \\
\hline SA & 0.961 & 41 & 0.175 & 0.955 & 28 & 0.262 \\
\hline SC & 0.977 & 41 & 0.560 & 0.925 & 28 & 0.046 \\
\hline Overall burden & 0.922 & 41 & 0.008 & 0.958 & 28 & 0.315 \\
\hline Mental burden & 0.945 & 41 & 0.048 & 0.902 & 28 & 0.012 \\
\hline Physical burden & 0.883 & 41 & 0.001 & 0.812 & 28 & 0.000 \\
\hline Time pressure & 0.875 & 41 & 0.000 & 0.844 & 28 & 0.001 \\
\hline Performance & 0.896 & 41 & 0.001 & 0.915 & 28 & 0.026 \\
\hline Effort & 0.927 & 41 & 0.011 & 0.821 & 28 & 0.000 \\
\hline Frustration & 0.807 & 41 & 0.000 & 0.848 & 28 & 0.001 \\
\hline
\end{tabular}

Tab. 2. Differences between study group and control group in CISS questionnaire scales.

\begin{tabular}{|c|c|c|c|c|c|c|c|}
\hline Scale & Group & $n$ & Mean & $\begin{array}{l}\text { Standard } \\
\text { deviation }\end{array}$ & $t / z$ & df & $\mathbf{p}$ \\
\hline \multirow{2}{*}{ TO } & Study & 41 & 65.12 & 6.71 & \multirow{2}{*}{2.272} & \multirow{2}{*}{44.97} & \multirow{2}{*}{0.028} \\
\hline & Control & 28 & 60.39 & 9.52 & & & \\
\hline \multirow{2}{*}{ EO } & Study & 41 & 36.76 & 9.98 & \multirow{2}{*}{-4.047} & \multirow{2}{*}{67} & \multirow{2}{*}{0.000} \\
\hline & Control & 28 & 45.79 & 7.62 & & & \\
\hline \multirow{2}{*}{ AO } & Study & 41 & 42.93 & 11.99 & \multirow{2}{*}{-1.606} & \multirow{2}{*}{66.97} & \multirow{2}{*}{0.113} \\
\hline & Control & 28 & 46.86 & 8.33 & & & \\
\hline \multirow{2}{*}{ ACZ } & Study & 41 & 18.12 & 6.81 & \multirow{2}{*}{-1.208} & \multirow{2}{*}{67} & \multirow{2}{*}{0.231} \\
\hline & Control & 28 & 20.07 & 6.23 & & & \\
\hline \multirow{2}{*}{ PKT } & Study & 41 & 16.78 & 4.42 & \multirow{2}{*}{-0.938} & & \multirow{2}{*}{0.348} \\
\hline & Control & 28 & 17.57 & 3.47 & & & \\
\hline
\end{tabular}


J.F. Terelak, A. Szewczyk - Differential Diagnosis...

Tab. 3. Differences between studied groups in NASA-TLX questionnaire scales.

\begin{tabular}{|c|c|c|c|c|c|c|}
\hline Scale & Group & $\mathbf{n}$ & Mean & Standard deviation & $\mathbf{z}$ & $\mathbf{p}$ \\
\hline \multirow{2}{*}{ Overall burden } & Study & 41 & 56.53 & 24.44 & \multirow{2}{*}{-3.770} & \multirow{2}{*}{0.000} \\
\hline & Control & 28 & 33.38 & 19.40 & & \\
\hline \multirow{2}{*}{ Mental burden } & Study & 41 & 48.66 & 25.79 & \multirow{2}{*}{-3.327} & \multirow{2}{*}{0.001} \\
\hline & Control & 28 & 28.75 & 20.26 & & \\
\hline \multirow{2}{*}{ Physical burden } & Study & 41 & 46.95 & 29.17 & \multirow{2}{*}{-3.179} & \multirow{2}{*}{0.001} \\
\hline & Control & 28 & 23.21 & 19.54 & & \\
\hline \multirow{2}{*}{ Time pressure } & Study & 41 & 62.32 & 30.54 & \multirow{2}{*}{-3.753} & \multirow{2}{*}{0.000} \\
\hline & Control & 28 & 32.86 & 26.79 & & \\
\hline \multirow{2}{*}{ Performance } & Study & 41 & 53.17 & 30.10 & \multirow{2}{*}{-2.212} & \multirow{2}{*}{0.027} \\
\hline & Control & 28 & 36.61 & 25.35 & & \\
\hline \multirow{2}{*}{ Effort } & Study & 41 & 53.29 & 25.68 & \multirow{2}{*}{-3.738} & \multirow{2}{*}{0.000} \\
\hline & Group & 28 & 27.14 & 21.36 & & \\
\hline \multirow{2}{*}{ Frustration } & Study & 41 & 28.90 & 24.12 & \multirow{2}{*}{-0.369} & \multirow{2}{*}{0.712} \\
\hline & Group & 28 & 36.07 & 30.65 & & \\
\hline
\end{tabular}

\section{DISCUSSION}

moderate difference between compared groups $(d=0.68)$.

Moreover, we demonstrated significant difference between study group and control group with regard to the tendency for emotion-oriented style $(t \quad 67)=-4.047 ; p<0.01)$. Control group obtained higher results in EO scale $(\mathrm{M}=45.79$; $\mathrm{SD}=$ $7.62)$ than the study group $(M=36.76 ; S D=0.98)$. Value of Cohen's $d$ coefficient $(d=0.99)$ implies great strength of acquired effect.

Table 3 presents differences between aircraft crews and control group with regard to the subjective assessment of task load assessed based on U Mann-Whitney test.

Hypothesis of existing differences between study and control group with regard to subjective assessment of task load was confirmed. Statistically significant differences were noted for overall NASA-TLX score and each one of its subscales except for frustration. In all cases aircraft crew obtained higher scores.

Moreover, analysis of differences with regard to subjective task load assessment was performed between all three subgroups of the study group. Beside pilots, cabin crew was also taken into consideration. Analysis conducted using Kruskal-Wallis test provided interesting results. It showed two statistically significant differences between cabin crew and pilots with regard to: physical burden scale $\left(c^{2} i^{2}=6.21 ; p<0.05\right)$ and effort scale $\left(c^{2} i^{2}=\right.$ 6.35; $p<0.05$ ). Cabin crew obtained higher results than pilots in both of these scales (respectively: $\mathrm{M}_{\text {overall burden }}=62.41 ; \mathrm{M}_{\text {physical burden }}=59.09 ; \mathrm{M}_{\text {effort }}=$ 62.50).
Differences between aircraft personnel and control group with regard to subjective task load are statistically significant for all scales of the NASA-TLX tool except for frustration scale, which corroborates with Hypothesis 1. Interpretation of those differences is related to a different structure of occupational tasks in both studied groups. Compared to salesmen [10], pilots and cabin crew [19] are exposed to greater burden, particularly in its mental and moral aspects, of tasks specific for this occupation and working conditions. Obtained data are of great informative value, as they emphasize the significance of subjective task load assessment as a substantial indicator of stress compared to formal physiological measurements of bodily activation.

Rather than physical effort, work of both pilots as well as cabin crew requires efficiency related to working at different hours, crossing time zones [6], but also mental performance associated with, e.g. patience toward other crewmembers, passengers, complying with procedures, etc. Additionally, awareness of responsibility for safety of passengers contributes to the feeling of moral pressure [27]. It is worth noting that only in the frustration scale the control group acquired higher results. Taking into consideration the fact that control group consisted of subjects representing different education levels (i.a. students, accountants, environmental architects, engineers, graduates of Polish studies), it could be explained ex post that task burden ensuing from their work, often not corresponding to their education, induces their frustration. On the other hand, aircraft crewmembers exposed to severe task load did not acquire 
high results on this scale, which might mean that they find their work, even though burdensome, quite satisfactory.

Responsibility that lies on the pilots during flight is one of the main factors influencing level of perceived task load-related stress [26]. Results of heart rate examination of the first pilot (aircraft Capitan) steering the plane and the second pilot responsible only for navigation and communication may serve as an example. Between 80 and 120 beats per minute were recorded in the former depending on the phase of flight (takeoff, midflight, landing), while values registered in the second pilot were significantly lower [14]. However, as shown by research studies, aircraft personnel deals with stress efficiently by choosing task-oriented coping strategies in comparison to control group, which prefers rather emotion-oriented strategies of coping with stress. It is in agreement with hypothesis 2 . One of the ways of coping with imposed task load related to aircraft crew team work includes crew resource management (CRM) training conducted by airlines [23].

Hypothesis no. 3 regarding pilots experiencing greater task load compared to cabin crewmembers was confirmed at the level of physical burden and effort. Acquired data allow a statement that cabin crew more severely experiences physical burden and effort related to work onboard than pilots working in the cockpit, as the cabin crew is responsible for safety onboard and attending to passengers. Activities related to physical effort (e.g. providing refreshments, sales onboard often con- ducted throughout the entire flight, cleaning after meals, etc.). Subjective sense of significant physical burden and effort perceived by cabin crew is objectively justified. It should be added that both pilots and cabin crew, particularly during transcontinental flights, have to work in different time zones, which is associated with chronobiological stress (e.g. circadian rhythm desynchronisation) [8] and may negatively influence performed tasks related to mental processes and perception [3].

Obtained data are of great informative value, as they indicate the significance of subjective assessment of task load as an important indicator of stress compared to formal physiological measurements of bodily activation, allowing for synergistic approach to their interrelationship [13].

\section{CONCLUSIONS}

In relation to the results of this study we may identify the following differences:

1. Between study group and control group with regard to subjective assessment of task load: physical, mental, time pressure, performance and effort, with the exception of the frustration scale,

2. Between aircraft personnel and control group with regard to styles of coping with stress: taskoriented and emotion-oriented,

3. Between cabin crew and pilots with regard to: physical burden and effort.

\section{AUTHORS' DECLARATION:}

Study Design: Jan F. Terelak, Aleksandra Szewczyk; Data Collection: Jan F. Terelak, Aleksandra Szewczyk; Statistical Analysis: Aleksandra Szewczyk; Manuscript Preparation: Jan F. Terelak; Funds Collection: Jan F. Terelak, Aleksandra Szewczyk. The Authors declare that there is no conflict of interest. 


\section{REFERENCES}

1. Biernacki M, Zieliński P. Analiza psychometryczna polskiego przekładu narzędzia do subiektywnej oceny obciążenia zadaniowego NASA-TLX. Polski Przegląd Medycyny Lotniczej 2010; 3:219-39.

2. Biernacki M, Bicka-Capała M, Tarnowski A. Teoretyczne i metodologiczne problemy badania obciążenia na przykładzie metody subiektywnego obciążenia pracą. Polski Przegląd Medycyny Lotniczej 2007; 4:465-79.

3. Damos DL, John RS, Lyall EA. Pilot Activities and the Level of Cockpit Automation. The International Journal of Aviation Psychology 2005; 3:251-68.

4. Endler NS, Parker JDA. Coping Inventory for Stressful Situations (CISS): Manual. Toronto: Multi-Health Systems, Inc; 1990.

5. Endler NS, Parker JDA. Assessment of multidimensional coping: task, emotion and avoidance strategies. Psychological Assessment 1994; 1:50-60.

6. Eriksen CA, Akerstedt T. Aicrew fatigue in trans-atlantic morning and evening flights. Chronobiology International 2006; 4:843-58.

7. Friedenberg J, Silverman G. Cognitive science. An introduction to the study of mind. (p.118-119). California: Sage Publications; 2006.

8. Gander PH, Signal L. Who is too old for shiftwork? Developing better criteria. Chronobiology International 2008; 2/3:199213.

9. Gore BF, Hoey BL, Wickens CD, Socash C, Gosakan M, Gacy M, Brehon DC, Fole. Workload as a Performance Shaping Factor in MIDAS v5. Presented at the Behavioral Representation in Modeling and Simulation (BRIMS) 2011, Sundance, UT.

10. Grebner S, Semmer NK, Faso LL, Gut S, Kalin W, Elfering A. Working conditions, well-being, and job-related attitudes among call centre agents. European Journal of Work and Organizational Psychology 2003; 4:341-365.

11. Grier R, Wickens C, Kaber D, Strayer D, Boehm-Davis D, Trafton JG, John MS. The Red-Line of Workload: Theory, Research, and Design. Proceedings of the Annual Meeting of the Human Factors \& Ergonomics Society 2008; 1204-08.

12. Hart SG, Staveland LE. Development of NASA-TLX (Task Load Index): Results of Empirical and Theoretical Research. In: Hancock PA, Meshkati N. ed. Human Mental Workload. Amsterdam: North Holland Press; 1988.

13. Jaremka LM, Lindgren ME, Kiecolt-Glaser JK. Synergistic relationships among stress, depression, and troubled relationships: Insight from psychoneuroimmunology. Expression and Anxiety 2013; 30:288-96.

14. Kantowitz BH, Casper PA. Human Workload in Aviation. In: Wiener EL, Nagel DC, eds. Human factors in Aviation. San Diego: Academic Press; 1988:170-73.

15. Kuliński M, Michalski R. Obciążenie pracą 2010; Retrieved 22.11.2013 http://ergonomia.ioz.pwr.wroc.pl/klasyczna-obciazenie_praca_php

16. Lazarus, RS, Folkman S. The stress and coping paradigm. New York: Springer; 1984.

17. Luximon A, Goonetilleke RS. Improvement of the subjective workload assessment technique. Ergonomics 2001; 3:229-43.

18. MacDonald W. The impact of job demands and workload on stress and fatigue. Australian Psychologist 2003; 2:102-17.

19. Nikolic MI, Orr JM, Sarter NB. Why pilots miss the greek box: How display cintext undermines attention capture. The International Journal of Aviation Psychology 2004; 1:39-52.

20. Parasumaran R, Hanckok PA. Adaptive Control of Mental Workload. In: Hanckok PA, Desmond PA eds. Stress, Workload and Fatigue. New York City: Lawrence Erlbaum; 2001:307-09.

21. Reason J T. Human Error. Cambridge: Cambridge University Press; 1990.

22. Reason J, Hollnagel E, Paries J. Revisiting the Swiss Cheese Model of Accident. Eurocontrol Experimental Centre $2006 ; 6$.

23. Seva, RR, Jennifer AM, Gutierrez A, Duh HB, Chong J. An Evaluation of CRM Attitudes of Filipino Pilots in Four Philippine Aviation Companies. The International Journal of Aviation Psychology 2007; 3:285-298.

24. Szczepaniak P, Strelau J, Wrześniewski K. Diagnoza stylów radzenia sobie ze stresem za pomocą polskiej wersji kwestionariusza CISS Endlera i Parkera. Przegląd Psychologiczny 1996; 1:187-210.

25. Terelak JF ed. Studia z psychologii stresu. Radzenie sobie ze stresem. Uwarunkowania i strategie. Warszawa: Wydawnictwa Akademii Teologii Katolickiej; 1997:29-43.

26. Terelak JF, Renowicka J. Konstrukcja i walidacja "Skali Źródeł Stresu w Pracy Stewardess Pokładowych”. Polski Przegląd Medycyny Lotniczej 2003; 3:255-263. 
27. Wickens CD, Mavor AS, McGee JP, eds. Flight to the future: Human factors in air traffic control. Washington, DC: National Academy Press; 1997.

28. Wiegmann DA, Shappell SA. A human error approach to aviation accident analysis. London: Ashgate Publishing Ltd; 2003.

Cite this article as: Terelak JF, Szewczyk A. Differential Diagnosis of Subjective Workload and Styles of Coping with Stress among Aircraft Crewmembers. Pol J Aviat Med Psychol, 2013; 19(4):11-18. 